\title{
Character Association and Variability Studies in Forage Sorghum
}

\author{
A.K. Toor* \\ Assistant Plant Breeder, Regional Research Station, Gurdaspur, India \\ *Corresponding author
}

\begin{tabular}{l} 
Ke y w o r d s \\
Sorghum, \\
heritability, \\
Correlation and \\
genetic parameters \\
\hline Article Info \\
$\begin{array}{l}\text { Accepted: } \\
15 \text { April } 2020 \\
\text { Available Online: } \\
10 \text { May } 2020\end{array}$ \\
\hline
\end{tabular}

\section{A B S T R A C T}

The present study was carried out to study the genetic variation, character correlation and path analysis of hybrids to understand the interrelationship of yield and it's attributing quantitative traits. A field experiment was conducted on multicut sorghum during the season 2015-2016 and 2016-2017, to investigate the genetic variability and phenotypic correlation between some yield and growth characters in forage sorghum. The experiment was laid in a randomized block design (RBD) with three replications. Characters studied included: growth attributes likeplant height $(\mathrm{cm})$, leaf length $(\mathrm{cm})$, leaf width $(\mathrm{cm})$, number of leaves, dry weight (q/ha) and green fodder yield(q/ha). All characters showed variability. The highest means were shown by green fodder yield $1025.6(\mathrm{q} / \mathrm{ha})$ followed by dry weight $226.71(\mathrm{q} / \mathrm{ha})$ and further by plant height $221.38(\mathrm{~cm})$. The greatest PCV and GCV was 16.49 and 14.53 by leaf width. Similarly, maximum heritability was for dry weight $98.61 \%$ followed by leaf width is $77.64 \%$. The agronomic trait like leaf width showed positive and significant correlation with number of leaves, dry weight and green fodder yield (q/ha) and also have shown positive association among themselves. Leaf length negatively correlated plant height, number of leaves per plant, dry weight and green fodder yield. Direct effect was highest for leaf width followed by dry weight. The study of various developmental and productive traits like leaf width and dry weight are helpful for framing the effective breeding programme and selection of yield related characters.

\section{Introduction}

Sorghum (Sorghum bicolor L Moench) is an important dual-purpose crop used as food and fodder crop. It occupies unique position in Indian Agriculture and cultivated in many parts of Asia and Africa. This crop ranks fourth after rice, wheat and maize and used for human as well as animal consumption (Rajput et al., 1983). Some species are used for making fodder and ethanol fuel production (Aml et al., 2012). In India, low fodder production and lesser-feed availability is the major limiting factor for increasing livestock productivity. The cropped area utilized to grow fodder is hardly 5\% in India causing it to deficit in dry fodder, green fodder and concentrates feed (Jain and Patel 2013). The common grazing lands are deteriorating quantitatively and qualitatively (Anomyous $e t$ al., 2012).

Sorghum is a palatable and nutritious fodder for animals. It is in enormous demand for 
green and dry fodder particularly during lean winter and summer season. Its fodder constitutes 20-45 per cent of the total dry weight of feed of dairy animals during normal season and upto 60 per cent during lean summer and winter season. In last 30 years, the role of sorghum as a major source of fodder has not weakened but its importance as a forage crop has increased (Toanapi et al., 2003).

Forage yield is a complex character, dependent on many character combinations, the major objective of sorghum breeding program. The study of inheritance of various developmental and productive traits through the estimation of different genetic parameters like genotypic and phenotypic coefficients of variability, heritability and genetic advance are helpful for framing the effective breeding programme. Inability to see small differences in quantitative traits among single plants have led to frequent challenge to find association among traits to more agreeable visual selection. The correlation coefficient gives a measure of the relationship between traits and provides the degree to which various characters of crop are associated with productivity. Selection based on yield components is advantageous if different yield related traits have been well documented (Pohelman et al., 1995).

Path analysis is an efficient statistical technique specially designed to quantify the interrelationship of different components and their direct and indirect effects on fodder yield. Through this yield contributing technique of characters can be ranked and specific traits producing a given correlation can be noticed (Rao et al., 2006). Therefore, present study was undertaken to assess correlation among the fodder yield and related traits with direct and indirect effects on green fodder yield of sorghum.

\section{Materials and Methods}

The present investigation was conducted at Regional Research Station, Gurdaspur with 10 genotypes of Sorghum during Kharif season, 2015-16 and 2016-17. The experiment was laid out in randomized block design (RBD) with three replications. Each genotype was grown in a plot size of $5 \times 2.5$ sqm with ten rows with row spacing of $25 \mathrm{~cm}$. All recommended management practices were followed during the crop period. Observations were recorded for leaf length $(\mathrm{cm})$, leaf width $(\mathrm{cm})$, plant height $(\mathrm{cm})$, number of leaves per plant, green fodder yield $(\mathrm{q} / \mathrm{ha})$ and dry weight ( $\mathrm{q} / \mathrm{ha})$ of two cuttings. Standard statistical procedures were used for genotypic and phenotypic coefficients of variation Burton (1952), heritability Hanson et al., (1956) and genetic advance Johnson (1955).Correlation coefficients were calculated as per Panse and Sukhatme (1967). Path analysis was done as per Dewey and Lu (1959). The mean of five plants in each replication for each character was used for analysis of variance. Softwares were used for analysis of correlation coefficient, path analysis and genetic variability parameters.

\section{Results and Discussion}

Sorghum is an important multicut fodder crop in lean season of summer. It provides green fodder to cattle all over India. Total green fodder yield for two years i.e. 2015 and 2016 is shown in Figure 1. In the following experiment last three entries are check i.e. entry 8, entry 9 and entry 10 are SSG59, $\mathrm{CSH}-24 \mathrm{MF}$ and CSH-20MF used for two seasons. Green fodder yield (GFY) was higher in year2015 as compared 2016. Entry 5 provided 3573.50 (q/ha) highest green fodder yield followed by entry 6which gave (3434.50q/ha) green fodder yield in both seasons. Entry 3, 4 and 7 produced moderate green fodder in quantity 3113, 3034 and 3092 
$q /$ ha. A lot of difference in yield of two years in entry 2, it might be due to lessor plant canopy growth. Thus, green fodder yield can be increased by following proper agronomic practices, timely irrigation and protection from abiotic and biotic stress. The three check entries showed less fodder yield less than entries.

\section{Analysis of variance}

The combined analyses of variance over the two planting years at Gurdaspur reveal that entries were significant at $1 \%$ level for all characters (Table 1). The data regarding means of all traits for sorghum hybrids for two years is presented in Table 2 is highly significant $(\mathrm{P}<0.1)$. All the characters showed significant difference among themselves based on coefficient of variation. The mean leaf length ranged (from 71.90-84.33cm), leaf breadth (from $3.06-5.83 \mathrm{~cm}$ ), plant height (from210.93-245.57 cm), number of leaves (8.53-10.93), dry weight (from 204.15-289.82 $\mathrm{q} / \mathrm{ha}$ ) and green fodder yield (from 895.07$1191.20 \mathrm{q} / \mathrm{ha}$ ) in Table 2. The variation between genotypes under all studied traits might be due to genetic behavior in combination with environmental factors, which might be suitable for one genotype than other. House (1985) and Mahdy et al., 2011 reported these findings are in agreement.

\section{PCV and GCV}

The total variation present in genotypes arises due to phenotypic, genotypic and environmental effects is presented in Table 3, Fig 2. Therefore, it is essential to divide changeability into its heritable and nonheritable components to restore to assessment of genetic parameters such as genotypic coefficient of variation (GCV) and phenotypic coefficient of variation (PCV). The classification of PCV and GCV into low (0$10 \%)$, moderate $(10.1-20 \%)$ and high $(>20 \%)$ was reported by (Sivasubramanian and Madhavamenon, 1973). As the result on the component of variance revealed that most the traits had moderate to low values of phenotypic and genotypic coefficients of variation (PCV and GCV respectively) among the sorghum accessions (Table 3). The PCV values range from 12.35 for dry weight to 16.49 for leaf width. Leaf width, dry weight and green fodder yield have moderate PCV values (Fig. 2). The PCV for leaf length (5.93), plant height (8.25) and number of leaves per plant (8.86) have low phenotypic coefficient of variation. Kumabhat et al., (2020) reported moderate and low phenotypic variation in fennel progenies for seed yield per plant $(25.559 \%)$ followed by umbels per plant $(23.056 \%)$, seeds per umbel $(22.249 \%)$, umbellets per umbel $(20.041 \%)$, branches per plant (13.907\%), plant height (10.179\%), 1000-seed weight $(8.715 \%)$, whereas, minimum value of PCV was recorded for days to $50 \%$ flowering in S6 progenies of fennel. Mathur and Patil (1982) observed considerable variation among 20 varieties of fodder sorghum for plant height, number of leaves per plant, number of tillers per plant and dry matter yield. Bai (1988) evaluated 15 guinea grass clones and reported moderate phenotypic coefficient of variation $(35.8 \%)$ for green fodder yield per hill followed by leaf area index $(28.72 \%)$ and number of panicles per plot $(25.86 \%)$.

The moderate GCV values ranged from $12.26 \%$ for dry weight to $14.53 \%$ for leaf width (Table 3, Fig. 2). Plant height, leaf length, green fodder yield and number of leaves have low GCV. The results on variance component showed that the phenotypic variances PCVs were much higher than the genotypic variance GCV for all the characters, except for dry weight suggesting the least influence of environment in the expression of these characters (Fig 2).Low GCV reported by (Bello et al., 2007) was 
observed for days to maturity $(7.91 \%)$ which indicated that improvement of this traits through selection is less effective due to lack of genetic variability among the varieties which is the basic prerequisite in which positive response due to selection depends on which are supported by the present study. The values of PCV and GCV were low for three traits, which indicated that environment has no effect on characters under study. Our results were supported by Pawar et al., (1989) who reported low PCV and GCV for number of spikelets per spike and spike length in wheat. Borad et al., (1996) observed wide range of variation for all the nine characters studied in 49 genotypes of fodder sorghum. Mathur and Patil (1982) observed considerable variation among 20 varieties of fodder sorghum for plant height, number of leaves per plant, number of tillers per plant and dry matter yield.

\section{Heritability and genetic advance}

Heritability estimates ranged from $98.61 \%$ for dry weight to $15.96 \%$ for plant height. All traits recorded high heritability estimates in (Table 2) expect for plant height, which has moderate heritability of 15.96. Dry weight (q/ha) has highest heritability $98.61 \%$ followed by leaf width heritability $77.64 \%$. Green fodder yield has $57.47 \%$ heritability. The characters like Dry fodder yield II cut (kg/ha) was having higher GCV, PCV and genetic gain and high heritability (h2). The heritability (h2) was high for Dry fodder yield II cut (84.61), followed by regenerability score (79.01) and green fodder yield III cut was stated by (Bairwal et al., 2018). Sindhagi et al., (1970) studied parents, $\mathrm{F}_{1} \mathrm{~s}$ and $\mathrm{F}_{2} \mathrm{~s}$ of two intervarietal crosses of fodder sorghum and reported high heritability and genetic advance for plant height (82.14 and $37.62 \%)$ and for green fodder yield (86.05 and 72.47 $\%$ ) respectively. Also, the number of leaves recorded a heritability estimate of 59.03 per cent and genetic advance of 26.81 per cent. Jhorar and Paroda (1976) estimated high heritability values for leaf area (93.32\%), number of tillers per plant $(88.63 \%)$, plant height $(87.93 \%)$ green fodder yield $(87.50 \%)$ and dry matter yield $(86.93 \%)$ in forage sorghum. Singh (1982) reported high heritability estimates for plant height, leaf number, leaf yield and forage yield per plant and high genetic advance for leaf yield per plant. Desai et al., (2000) in fodder sorghum reported high heritability estimates for dry fodder yield, green fodder yield, plant height and total leaf area. The leaf number showed the highest heritability followed by dry matter yield, plant height and number of tillers per plant by Mathur and Patil (1982).

The plant height and number of leaves have moderate heritability (Table 3, Fig 3). Moderate heritability was recorded in forage sorghum for leaf: stem ratio, green fodder yield and dry fodder yield by Vaithialingham (1979). Moderate to high heritability estimates were observed for green fodder yield, plant height by Patil et al., (1996). Grain yield also showed moderate heritability value $(72.03 \%)$ across locations in wheat by Krishna et al., (2020).

The amount of genetic advance expected from selection can be achieved by estimating heritability along with coefficient of variability ensuring sufficient scope for their improvement through selection. The highest GAM was $26.37 \%$ for leaf width followed by dry weight $25.09 \%$. Mathur and Patil (1982) reported the highest genetic advance for number of leaves per plant. Singh (1982) reported high genetic advance for leaf yield per plant from a study on 21 varieties of sorghum for forage characters. Mahajan et al., (2011) also reported high value of expected genetic advance expressed as percent of mean for harvest index, plant height and panicle yield per plant. Sreekumar and Bai (1995) 
revealed that plant height and plant population had high genetic advance and heritability on genetic analysis of fodder maize for fodder yield and its components.

The moderate GAM for green fodder yield was $12.73 \%$. Moderate estimates of genetic advance as per cent mean were calculated for character like peduncle length (19.64), thousand kernel weight (13.40), spike length (12.48), iron content (11.88), plot yield (10.69) was reported by Krishna et al., (2020) in wheat. Moderate genetic gain was stated for leaf breadth (19.58) followed by leafstem ratio (18.21) and green fodder yield I cut (15.43) by Bairwal (2018 in sorghum.

Leaf length, plant height and number of leaves showed low GAM. Krishna et al., (2020) in wheat gave lower genetic advance was found in case of spikelet per spike (9.08), zinc content (8.20) and days to heading (7.53), plant height (7.15), biomass (5.56) followed by Soil Plant Analysis Development (SPAD) which had value of 4.59 and NDVI (4.51) days to maturity (4.34). The simple selection implied, the genetic material of sorghum under study can bring about significant improvement in these traits as the heritability and estimated genetic advance were moderate to high. Earlier workers reported that expressions for most of the characters was genetic, could be exploited in breeding programs and quantitative characters studies in sorghum genotypes (Basu et al., 1981). Bairwal (2018) reported low genetic gain was in protein percent (9.08) and plant height(6.11)in sorghum.

\section{Correlation analysis}

In plant breeding green fodder yield being the result of combined effects of several component characters and environment, understanding of the interaction of characters among themselves and with the environment is of great use. Correlation studies provide information on the nature and extent of association between any two pairs of metric characters and by genetic up gradation in one character by selection of the other of a pair. The accurate precision of experiment was verified to reflect the confidence in the estimation of real genotypic values from the phenotypic values. The presence of genetic variation indicates the possibility of selection gain. These results were also essential for accurate estimation of the correlations, since this parameter measures the joint variation of traits. Phenotypic correlations and genotypic correlation are estimates within the expected range (-1 to 1), allowing good inference (Table 4). The agronomic trait like leaf width showed positive and significant correlation with number of leaves, dry weight and green fodder yield ( $q /$ ha) and also have shown positive association among themselves (Table 4). Similarly, plant height was positively correlated to number of leaves, dry weight and genotypically to green fodder yield. Likewise, number of leaves positively correlated to dry weight and green fodder yield. Also, dry weight was correlated positively to green fodder yield. Badwal (1997) also observed that the plant positive correlation with yield and also yield (t/ha-1) was highly significant and positive correlation with number of heads per plot and number of grain per head. Manickam and Vijendradass (1994) reported positive association of plant height, number of tillers, number of leaves, leaf area per plant, dry matter yield and crude protein with green fodder yield per plant. Sainy and Paroda (1978) reported positive correlation of plant height with green fodder yield and dry fodder yield in sorghum.

Correspondingly, yield was positively correlated to grain per panicle reported by many workers: Dabholkar et al., (1970) and Abifarin and Pickett (1970). Highest value of positive and significant correlation was 
observed between green fodder yield and number of leaves/plant, closely followed by green fodder yield and plant height
(0.89950.8828) was reported in Napier Bajra by Kapoor et al., (2017).

Table.1 Mean Analysis of variance for pooled data of sorghum fodder

\begin{tabular}{|c|c|c|c|c|c|c|c|}
\hline SOURCE & DF & LL & LW & PH & NOL & DW & GFY \\
\hline REPL & 2 & 409.64 & 1.21 & 4481.46 & 3.50 & 397.55 & 33143.36 \\
\hline TREAT & 9 & 1627.88 & 59.22 & 15861.10 & 49.86 & 83944.95 & 941449.71 \\
\hline ERROR & 18 & 727.18 & 10.37 & 20206.26 & 33.91 & 783.09 & 372538.69 \\
\hline CV\% & & 4.03 & 7.79 & 7.56 & 6.90 & 1.45 & 7.01 \\
\hline
\end{tabular}

Table.2 Means of green fodder yield and associated characters for two years

\begin{tabular}{|c|c|c|c|c|c|c|}
\hline Entries & $\begin{array}{c}\text { Leaf Length } \\
(\mathbf{c m})\end{array}$ & $\begin{array}{c}\text { Leaf breadth } \\
(\mathbf{c m})\end{array}$ & $\begin{array}{c}\text { Plant Height } \\
(\mathbf{c m})\end{array}$ & $\begin{array}{c}\text { Number of } \\
\text { leaves }\end{array}$ & $\begin{array}{c}\text { Dry weight } \\
\text { (q/ha) }\end{array}$ & $\begin{array}{c}\text { Green fodder } \\
\text { yield (q/ha) }\end{array}$ \\
\hline Entry1 & 77.03 & 4.90 & 239.76 & 10.20 & 217.65 & 965.73 \\
\hline Entry 2 & 75.20 & 5.43 & 217.27 & 10.93 & 263.48 & 902.93 \\
\hline Entry 3 & 77.10 & 5.03 & 223.40 & 9.58 & 204.15 & 1037.73 \\
\hline Entry 4 & 77.63 & 5.09 & 213.17 & 9.50 & 209.30 & 1011.33 \\
\hline Entry 5 & 80.03 & 5.12 & 213.67 & 9.53 & 222.53 & 1191.20 \\
\hline Entry 6 & 71.90 & 5.12 & 223.53 & 10.35 & 289.82 & 1144.93 \\
\hline Entry 7 & 78.27 & 4.46 & 245.57 & 9.88 & 217.40 & 1030.67 \\
\hline Entry 8 & 84.33 & 3.06 & 210.93 & 8.53 & 212.70 & 895.07 \\
\hline Entry 9 & 84.13 & 4.63 & 211.62 & 10.40 & 224.87 & 1023.60 \\
\hline Entry 10 & 81.43 & 5.83 & 214.90 & 10.43 & 205.20 & 1052.80 \\
\hline Means & 78.70 & 4.86 & 226.71 & 9.93 & 221.38 & 1025.6 \\
\hline CV \% & 4.03 & 7.79 & 7.56 & 6.90 & 1.45 & 7.01 \\
\hline
\end{tabular}

Table.3 Genetic variability analysis of among Sorghum genotypes

\begin{tabular}{|l|c|c|c|c|c|c|}
\hline \multicolumn{1}{|c|}{ Characters } & GMean & PCV & GCV & h2 & GA & GAM \\
\hline Leaf length (cm) & 157.41 & 5.93 & 4.34 & 53.68 & 10.32 & 6.56 \\
\hline Leaf width (cm) & 9.73 & 16.49 & 14.53 & 77.64 & 2.56 & 26.37 \\
\hline Plant Height (cm) & 442.76 & 8.25 & 3.29 & 15.96 & 12.01 & 2.71 \\
\hline No. of leaves/plant & 19.86 & 8.86 & 5.55 & 39.27 & 1.42 & 7.17 \\
\hline Dry Weight(q/ha) & 453.41 & 12.35 & 12.26 & 98.61 & 113.79 & 25.09 \\
\hline Green fodder yield (q/ha) & 2051.20 & 10.75 & 8.15 & 57.47 & 261.18 & 12.73 \\
\hline
\end{tabular}


Table.4 Correlation analysis for various characters in Sorghum

\begin{tabular}{|c|c|c|c|c|c|c|c|}
\hline Characters & $\begin{array}{l}\text { Rg } \\
\text { or } \\
\text { rp }\end{array}$ & $\begin{array}{l}\text { Leaf } \\
\text { length } \\
(\mathrm{cm})\end{array}$ & $\begin{array}{c}\text { Leaf } \\
\text { width } \\
\text { (cm) }\end{array}$ & $\begin{array}{c}\text { Plant } \\
\text { Height } \\
\text { (cm) }\end{array}$ & $\begin{array}{c}\text { No. of } \\
\text { leaves/plant }\end{array}$ & $\begin{array}{c}\text { Dry } \\
\text { Weight } \\
\text { (q/ha) }\end{array}$ & $\begin{array}{l}\text { Yield } \\
\text { (q/ha) }\end{array}$ \\
\hline \multirow[t]{2}{*}{ Leaf length $(\mathrm{cm})$} & $\mathrm{rg}$ & 1.000 & -0.6182 & $-0.9675 * *$ & $-0.7030 *$ & $-0.7332 *$ & -0.2694 \\
\hline & $\mathrm{rp}$ & 1.000 & -0.3145 & -0.1199 & -0.1819 & -0.5574 & -0.1795 \\
\hline \multirow[t]{2}{*}{ Leaf width $(\mathrm{cm})$} & rg & & 1.000 & 0.0879 & $0.8592 * *$ & 0.2030 & 0.5038 \\
\hline & $\mathrm{rp}$ & & 1.000 & -0.0550 & $0.6367 *$ & 0.1833 & 0.3026 \\
\hline \multirow[t]{2}{*}{ Plant Height (cm) } & rg & & & 1.000 & 0.0863 & 0.0124 & 0.0902 \\
\hline & $\mathrm{rp}$ & & & 1.000 & 0.2233 & 0.0073 & -0.0786 \\
\hline \multirow[t]{2}{*}{ No. of leaves/plant } & $\mathrm{rg}$ & & & & 1.000 & 0.6107 & 0.0852 \\
\hline & $\mathrm{rp}$ & & & & 1.000 & 0.4125 & 0.0593 \\
\hline \multirow[t]{2}{*}{ Dry Weight(q/ha) } & rg & & & & & 1.000 & 0.1840 \\
\hline & $\mathrm{rp}$ & & & & & 1.000 & 0.1594 \\
\hline \multirow{2}{*}{$\begin{array}{l}\text { Green fodder } \\
\text { Yield (q/ha) }\end{array}$} & $\mathrm{rg}$ & & & & & & 1.000 \\
\hline & $\mathrm{rp}$ & & & & & & 1.000 \\
\hline
\end{tabular}

Significant at $1 \%$ and $5 \%$

Table.5 Path analysis for various character of sorghum

\begin{tabular}{|c|c|c|c|c|c|c|}
\hline Parameters & $\begin{array}{c}\text { Leaf length } \\
\text { (cm) }\end{array}$ & $\begin{array}{c}\text { Leaf } \\
\text { width } \\
\text { (cm) }\end{array}$ & $\begin{array}{c}\text { Plant } \\
\text { Height } \\
\text { (cm) }\end{array}$ & $\begin{array}{c}\text { No. of } \\
\text { leaves/plan } \\
\mathbf{t}\end{array}$ & $\begin{array}{c}\text { Dry } \\
\text { Weight } \\
\text { (q/ha) }\end{array}$ & $\begin{array}{c}\text { Yield(q/ha) } \\
\text { Dependent } \\
\text { variable }\end{array}$ \\
\hline Leaf length (cm) & $\mathbf{- 1 . 0 2 6 0}$ & -2.0358 & 0.8173 & 2.9640 & 0.9890 & 0.2694 \\
\hline Leaf width (cm) & 0.6343 & $\mathbf{3 . 2 9 3 1}$ & -0.0743 & -3.6230 & 0.2738 & 0.5038 \\
\hline $\begin{array}{c}\text { Plant Height } \\
\text { (cm) }\end{array}$ & 0.9926 & 0.2895 & $\mathbf{- 0 . 8 4 4 8}$ & -0.3638 & 0.0167 & 0.0902 \\
\hline $\begin{array}{c}\text { No. of } \\
\text { leaves/plant }\end{array}$ & 0.7212 & 2.8296 & -0.0729 & $\mathbf{- 2 . 2 1 6 5}$ & 0.8238 & 0.0852 \\
\hline $\begin{array}{c}\text { Dry } \\
\text { Weight(q/ha) }\end{array}$ & 0.7522 & 0.6683 & -0.0105 & -2.5749 & $\mathbf{1 . 3 4 8 9}$ & 0.1840 \\
\hline
\end{tabular}

Figure.1 Pooled green fodder yield of sorghum for two years

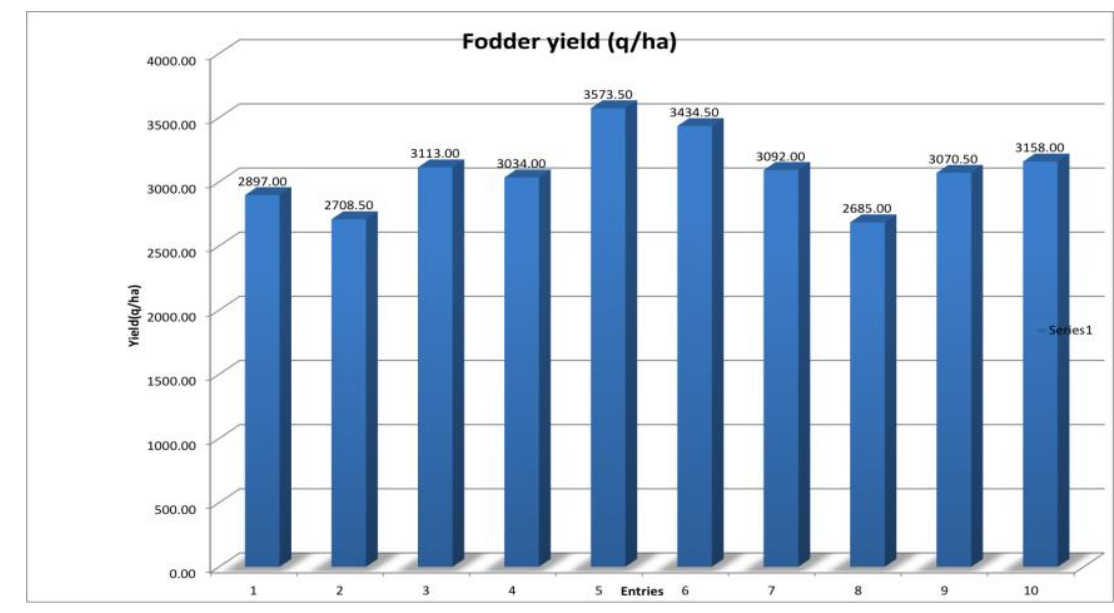


Fig.2 PCV and GCV of green fodder yield and associated traits

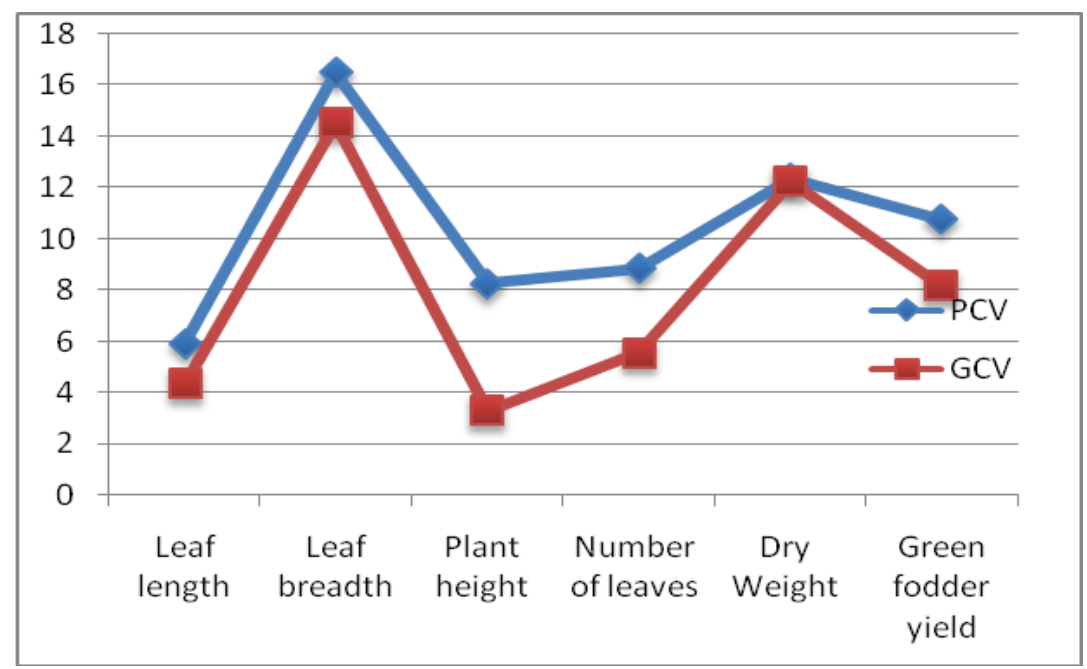

Fig.3 Heritability and GAM for green fodder yield and associated characters

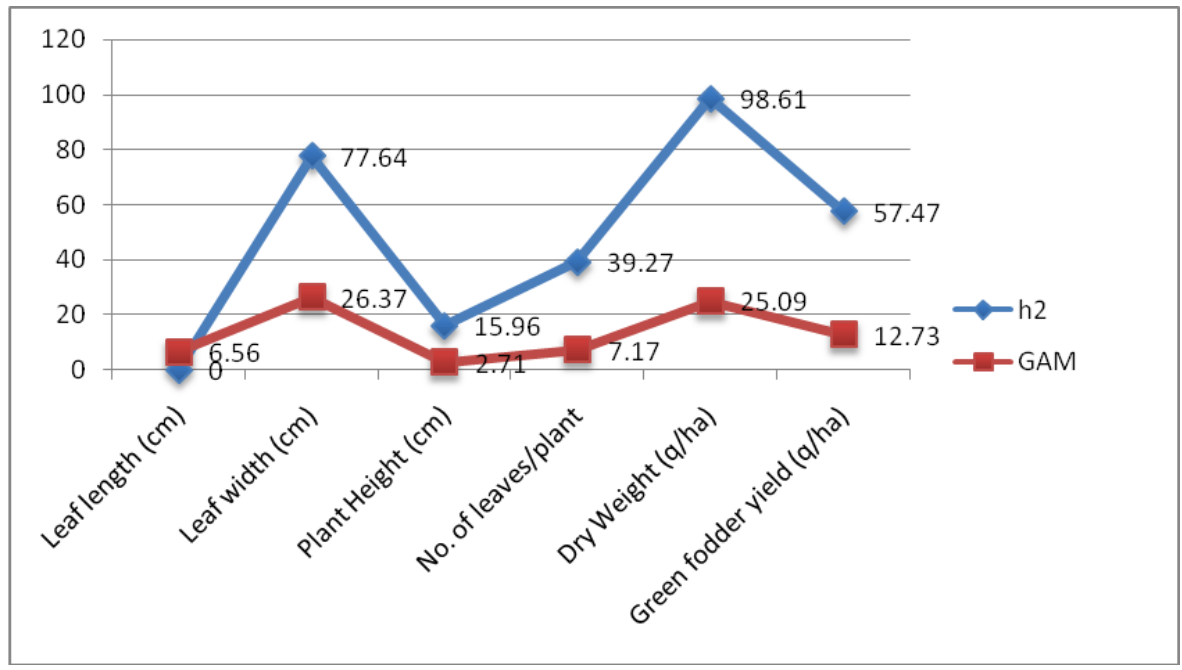

Similarly, leaf length negatively correlated leaf width, plant height, number of leaves per plant, dry weight and green fodder yield (Table 4). Likewise, leaf width negatively and phenotypically correlated to plant height (0.0550) and also plant height phenotypically and negatively correlated to green fodder yield (-0.0786). Similar relationships were recorded in other studies on sorghum Murray et al., (2008) and Zhao et al., (2009). Acid detergent fibre and crude protein $(-0.8708$, 0.8506 ) exhibited highest value of negative and significant correlation in Napierbajra (Kapoor et al., 2017). Vaidyanathan (1982), reported negative correlation between leaf:stem ratio and fodder yield. Suresh and Bai (1998) in fodder bajra, reported that dry matter had the highest positive and negative genotypic correlations with crude protein content and internode length respectively.

\section{Path analysis}

Correlation coefficients are not considered to 
determine traits as selection criteria. In agriculture, path analyses have been used by plant breeders to assist in identifying traits that are useful as selection criteria to improve crop yield (Dewey and Lu, 1959). The path analysis was conducted to determine direct and indirect effects of traits on sorghum fodder yield. The partitioning of genotypic correlation coefficient was done into direct and indirect effects and results were displayed in (Table 5). Out of 6 characters most of them showed positive direct effects. In present study, green fodder yield was considered as dependent character and others were considered independent. Leaf width showed maximum direct effect on green fodder yield (3.2931) followed by dry weight (1.3489) and other traits viz leaf length, plant height and number of leaves have negative direct effect. Similar results were obtained by Aml et al., (2012), they found that panicle length and number of grains /panicle has positive direct effect on grain weight/ panicle. Bini and Bai (2005) in fodder sorghum reported that leaf weight per plant; leaf area index and plant height at harvest had positive direct effect on green fodder yield alongwithhigh genotypic correlation.

The path analysis (Table5) showed leaf length had positive indirect effect on leaf width, plant height number of leaves and dry weight $(0.8173,2.9640,0.9890$ and 0.2694$)$. The dry weight and leaf length had negative direct effect. Similarly, leaf width has positive indirect effect for leaf length, dry weight and green fodder yield $(0.6343,0.2738$ and 0.5038). Likewise, plant height, number of leaves and dry weight showed positive and indirect effect with leaf length, leaf width, dry weight and green fodder yield. According to Lorentz et al., (2006), the direct effect is negative or negligible, the relationship was caused by indirect effects, which was observed in the present analysis. Similar results were obtained by Entringer (2014) in super sweet corn, used production components and determined that only two of the eight variables had a direct effect on the basic variable, whereas the others occurred, by an indirect effect. Bairwal (2018) reported positive as well negative direct and indirect effects for different traits in fodder sorghum.

In conclusion, the analysis of two-year data the results obtained from correlation studies and path analysis indicated that leaf width and dry weight yield have positive association and positive direct effects. Hence, selection for these characters could bring improvement in green fodder yield and its components.Leaf width, dry weight and green fodder yield showed high heritability associated with high genetic advance from selection, indicating that the type of gene action dominated in the inheritance of these traits is additive, which means that there are good opportunities to get success in improvement of these traits via selection procedures. Results concluded that leaf width is good selection criterion for green fodder yield and, therefore, selection for tall sorghum plants would increase grain yield.

\section{Acknowledgement}

The author is grateful to Dr RS Sohu for providing seed material from Department of Plant Breeding and Genetics, Punjab Agricultural University, Ludhiana.

\section{References}

Abifarin, A. O. and Pickett, R. C.1970. Combining ability and heterosis for yield, protein, lysine and certain plant characters in 18 diverse inbreds and 65 hybrids in (Sorghum bicolor (L.) Moench). African Soil. 15: 399-416

Aml A. Tag El-Din, Eatemad M. Hessein and E.A. Ali 2012. Path Coefficient and Correlation Assessment of Yield and Yield Associated Traits in Sorghum 
(Sorghum bicolor L.) Genotypes. American-Eurasian J. Agric. \& Environ. Sci., 12 (6): 815-819

Anonymous 2012. Report of the working group on animal husbandry and dairying12th five years plan. Planning Commission Government of India New Delhi. 2012; PP 1-128.

Badwal, S. S.1997 Correlation between grain and fodder yield in Jowar. Madras Agri. Jour.; 58:531-533

Bai, V.T. 1988. Production potential of guinea grass clones under partial shade in coconut gardens. MSc. (Ag.) thesis, Kerala Agricultural University, Thrissur, p. 68

Bairwal LL 2018Variability, Correlation and Path Analysis in Multicut Forage Sorghum [Sorghum bicolor (L.) Moench MPUAT Thesis.

Basu, A.K. 1981.Variability and Heritability Estimate from Inter-Season Sorghum Cross. Indian Journal of Agricultural Science, 41, 116-117.

Bello D, Kadams AM, Simon SY and Mashi DS. 2007. "Studies on genetic variability in cultivated sorghum (Sorghum bicolor L. Moench) cultivars of Adamawa State Nigeria," AmericanEurasian Journal Agricultural Environment Science, vol. 2, no. 3, pp. 297-302.

Bini, K and Bai, D.I.S. 2005. Correlation and Path analysis in fodder sorghum. Forage Research.30(4): 238-239.

Borad, V.P., Patel, J.R. and Patel, N.M. 1996. Variablity in qualitative characters of forage sorghum [Sorghum bicolor (L.) Moench]. Gujarat Agric. Univ. Res. J. 21: $17-20$

Burton GW. 1952. Quantitative inheritance in grasses. Proceedings of sixth International Grassland Congress 1: 277-288

Dabholkar, A. R., Telang, S. W. and Patal, K. C. 1970. Correlations in sorghum hybrids. Sci. Cult., 36: 466

Desai, S.A., Singh, R. and Shrotia, S.R. 2000. Variability and heterosis for forage yield and its components in interspecific crosses of forage sorghum. Karnataka $\mathbf{J}$. agric. Sci. 13: 315-320

Dewey DR, Lu KH. 1959. A correlation and path coefficient analysis of components of crested wheatgrass seed production. Agronomy Journal 51:515-518.

Entringer GC, Santos PHAD, Vettorazzi JCF, Cunha KS, et al., 2014. Correlação e análise de trilhaparacomponentes de produção de milhosuperdoce.Rev. Ceres 61: $356-$

361http://dx.doi.org/10.1590/S0034737X2014000300009

Hanson CH, Robinson HF, Comstock RE. 1956. The biometrical studies on yield in segregating population of Korean lespedeza. Agronomy Journal 48:268272.

House, L.R., 1985. A guide to Sorghum Breeding. 2ndEd. International Crops Research Institute for the Semi-Arid Tropics, Patancheru, India, pp: 206 http://dx.doi.org/10.1023/A:10096731 26345

Jain, S.K., M. Elangovan and N.V. Patel. 2010. Correlation and path coefficient analysis for agronomic traits in forage sorghum (Sorghum bicolor L. Moench). Indian J. Plant Genet. Resour. 23(1): $15-18$

Johnson, H. W., Robinson, H. F. and Comstock, R.E. 1955. Estimates of genetic and environmental variability in soybean. Agronomy Journal, 47: 314318.

Jhorar, B.S. and Paroda, R.S. 1976. Correlation and path analysis in forage sorghum. Forage Res. 2: 151-157

Kapoor R (2017). Genetic variability and association studies in Napier grass (Pennisetum purpureum schumach.) for green fodder yield and quality traits. 
Electronic Journal of Plant Breeding, 8(3): 885-891

Krishna S, Upadhayay P, Mishra VK, Kujur SN, Kumar M and Yadav PS 2020. Genetic Analysis and Diversity Study among High Zinc Wheat (Triticum aestivum L.) Germplasm Int.J.Curr.Microbiol.App.Sci(2020) 9(3): 942-953

Kumawat SK, Rachhoya HK, Sharma M, Singh D and Sastry, E. V. D. 2020. Correlation and Path Coefficient Analysis for Yield and Yield Component Traits in S6 Progenies of Fennel (Foeniculum vulgare Mill.). Int.J.Curr.Microbiol.App.Sci. $\quad 9(03)$ : $152-158$

Lorentz LH, Fortes FO and Lúcio AD (2006). Path analysis in seed analyzes of exotic forest species of Rio Grande do Sul. Rev. Tree. 30: 567-574.

Mahdy, E.E., M.A. Ali and A.M. Mahmou, 2011. The effect of Environment on combining ability and heterosis in grain sorghum (Sorghum bicolor L. Moench).Asian Journal of Crop Science, 3(1): 1-15.

Mahajan, R.C., P.B. Wadikar, S.P. Pole and M.V. Dhuppe, 2011. Variability, correlation and path analysis studies in sorghum. Research Journal of Agricultural Sciences, 2(1): 101-103.

Manickam, S. and L.D. Vijendra Das. 1994. Character association and path analysis in forage sorghum. Mysore $\mathbf{J}$ of Agriculture Science 28:116-119

Mathur, P.N. and Patil, B.D. 1982. Genetic variability, correlation and path analysis in forage sorghum. Indian J. agric. Res. 16: $269-272$

Murray, S.C., Rooney, W.L., Mitchell, S.E., Sharma, A., Klein, P.E., Mullet, J.E. and Kresovich, S. (2008) Genetic Improvement of Sorghum as a Biofuel Feedstock: II. QTL for Stem and Leaf Structural Carbohydrates. Crop Science,
48, 2180-2193. http://dx.doi.org/ 10.2135/cropsci2008.01.0068. Mysore J. Agric. Sci. 28: 116-119

Panse, V. G., and Sukhatme, P. V. (1967). Statistical Methods Agricultural Workers, published by Indian Council of Agricultural Research. New Delhi (India).

Pawar, S. V., and Patil, R. B. (1989). Variability and inheritance of yield components in crosses of wheat. Journal Maharashtra Agricultural University, 14: 25-37.

Pohelman JM, 1995. The mungbean. Oxford and IBH publishing Co. Pvt. Ltd., New Delhi. pp.1-375.

Rajput FK, Arain MJ and Khawja KB 1983. Effect of row spacing and fertilizer level on yield and growth of sorghum.Pak $\mathbf{J}$ of Agric Res.,4:166

Rao CM, Rao YK, Reddy M. 2006.Genetic variability and path analysis in mungbean. Legume Res., 29:

Sainy, M.L. andParoda, R.S. 1978. Correlation and path coefficient analysis in sorghum. Genet. Agr.32: 99-107

Sindhagi, S.S., Swarup, V. and Singh, D. 1970.Variation and heritability of some quantitative characters in F2progenies of intervarietal crosses of sorghum. Indian J. Genet. 30: 660-664

Singh, M. P. 1982. Studies on genetic variability in quantitative characters contributing to forage yield in jowar. M.Sc.(Ag.) thesis, Indian Agricultural Research Institute, New Delhi, p.85

Singhania, D.L., Ratnagar, V.P., Gupta, S.C. and Singh, V. 1977. Genetic analysis of forage yield and quality in sorghum. Indian J. Genet. 37: 235-240

Sivasubramanian S and Madhava Menon P 1973. Genotypic and phenotypic variability in rice. Madras Agri. J. 60(912):1093-96

Sreekumar, S.G. and Bai, D.I.S. 1995. Genetic analysis of yield and its 
components in fodder maize. J. tropic. Agric. 38: 8-10

Suresh, S. and Bai, D.I.S. 1998. Genetic variability in fodder bajra. Forage Res. 24: $175-176$

Tonapi VA, Patil JV, DayakarRao B, Elangovan M, VenkateshBhat and Raghavendra Rao KV. Sorghum: Vision 2030. Directorate of Sorghum Research, Rajendranagar, Hyderabad 500030 (AP), India. 2011; 38 pp.

Vaidyanathan, P.1982.Combining ability and character association studies for attributes related to fodder production in sorghum [Sorghum bicolor (L.) Moench]. Ph.D thesis, Tamil Nadu
Agricultural University, Coimbatore, $\mathrm{p}$. 135

Vaithialingham, R. 1979. Genetic analysis of fodder yield components in sorghum (Sorghum bicolor (L.) Moench). Ph.D thesis, Tamil Nadu Agricultural University, Coimbatore p. 128

Zhao, Y.L., Dolat, A., Steinberger, Y., Wang, X., Osman, A. and Xie, G.H. (2009) Biomass Yield and Changes in Chemical Composition of Sweet Sorghum Cultivars Grown for Biofuel. Field Crops Research, 111, 5564.http://dx.doi.org/10.1016/j.fcr.2008.1 0.006

\section{How to cite this article:}

Toor, A.K. 2020. Character Association and Variability Studies in Forage Sorghum. Int.J.Curr.Microbiol.App.Sci. 9(05): 1679-1690. doi: https://doi.org/10.20546/ijcmas.2020.905.189 